\title{
The Trafficking Defence: A Proposed Model for the Non-Criminalisation of Trafficked Persons in International Law
}

Bijan Hoshi ${ }^{1}$

DOI: $10.21827 / 5 a 86 a 78872676$

\author{
Keywords \\ Trafficking in Persons, Non-Criminalisation, Causation-Based, Compulsion- \\ BASED, DEFENCES
}

\begin{abstract}
Trafficked persons are often re-traumatised by being criminalised for offences that they have committed as a result of their status as trafficked persons. This paper argues that in the absence of a binding international law model for the non-criminalisation of trafficked persons, there is no unified vision of non-criminalisation to which regional and national legislators may (or must) adhere. As a result, the existing provisions giving effect to the noncriminalisation principle at the regional level in Europe and the national level in the United Kingdom are deficient in two significant respects: first, they require that the offence was committed under a high degree of pressure (rather than being a direct consequence of the trafficking situation); and, secondly, they are qualified (because non-criminalisation is discretionary). A model is proposed for the non-criminalisation of trafficked persons in international law to be incorporated into the international legal framework through an amendment to the Trafficking Protocol in the form of an additional clause empowering trafficked persons to protect themselves against criminalisation by way of a positive defence; the trafficking defence.
\end{abstract}

\section{Introduction}

The experiences to which trafficked persons are subjected cause severe and enduring psychological traumatisation. This traumatisation is exacerbated and entrenched when the trafficked person is subsequently treated as a criminal for offences committed as result of the trafficking situation (commonly, offences relating to their immigration status, prostitution or drugs trafficking). Minimally, the process of criminalisation is likely to involve being arrested and interviewed by law enforcement officers, at least one court appearance, some form of penalty and the imposition of a permanent criminal record. Maximally, it may additionally involve pre-trial detention, a series of court appearances including an extended trial, which would probably require the trafficked person to give evidence (including crossexamination on their "claim" of being a trafficked person) and a lengthy sentence of imprisonment. Each stage of the process of criminalisation disempowers and re-traumatises trafficked persons and, fundamentally, fails to recognise that they themselves are victims of crime.

Bijan Hoshi is a barrister of the Supreme Court of England and Wales. He practices in human rights and public law at Garden Court Chambers, London. 
Proper recognition of the victim status of trafficked persons requires the application of the principle of non-criminalisation: 'Criminalisation is the antithesis of the victim-centred approach, inevitably operating to deny trafficked persons the rights to which they are entitled under international law.' ${ }^{2}$ In broad terms, the non-criminalisation principle recognises that trafficked persons should not be criminalised for the offending behaviour in which they engaged as a result of their being trafficked. The recognition of the centrality of this principle is not novel; indeed, 'there is considerable and growing evidence that the policy preference for victims of trafficking not to be subject to criminalisation is evolving into a widely accepted normative standard.' ${ }^{3}$ This acceptance is demonstrated by the inclusion of non-criminalisation provisions in legal frameworks at international, regional and national levels. ${ }^{4}$ Despite this, the inadequacy of these provisions means that the criminalisation of trafficked persons continues unabated. ${ }^{5}$

The fundamental reason for this inadequacy is the narrow scope of existing provisions. There are two prisms through which the principle of non-criminalisation has been interpreted: (1) causation-based, which requires that the criminal act be a direct result of the trafficking situation; and, (2) compulsion-based, which requires that the criminal act is committed under a high degree of pressure from the trafficker(s). ${ }^{6}$ The latter prism provides insufficient protection for victims of trafficking for two reasons. First, it fails to grasp the subtle and nefarious methods by which traffickers can exert total dominance over trafficked persons, such that even in the absence of a high degree of pressure (or, indeed, any overt pressure at all), the trafficked person may, in reality, have little choice but to commit the criminal act. Secondly, it fails to recognise that a clear causal relationship between the criminal act and the trafficked status of the trafficked person may remain even after the trafficking situation has ended. Conversely, the former prism covers all offences committed as a direct consequence (broadly construed) of the trafficking situation. This broader protection encompasses criminality committed by the trafficked person when under the control of the trafficker, when attempting to flee the control of the trafficker or when 'otherwise acting to try to protect or assist him or herself on account of their trafficked status'. ${ }^{7}$ Unfortunately, in the absence of a binding, hard-law provision of international law that mandates a causation-based approach, regional and national legislators are free to adopt compulsion-based models, and have done so.

This article proposes a model for the non-criminalisation of trafficked persons in international law. The proposed model consists of the introduction of a binding, causationbased non-criminalisation provision in international law which arms trafficked persons with a positive defence against criminalisation: the trafficking defence. The second and third

2 Gallagher, A., The International Law of Human Trafficking, Cambridge University Press, Cambridge, 2010, 283; Attar, M. Y., "Incorporating the Five Basic Elements of a Model Antitrafficking In Persons Legislation in Domestic Laws: From the United Nations Protocol to the European Convention", Tulane Journal of International and Comparative Law, 14, 2006, 357-420, 380-1.

3 Gallagher, A., Idem, 285.

4 See part II, below.

5 See, for example: Drew, S., Human Trafficking - Human Rights: Law and Practice, LAG, London, 2009, 172-178; Cross, L., "Slipping Through the Cracks: The Dual Victimization of Human-Trafficking Survivors", McGeorge Law Review, 44, 2013, 395-422, 396-397; Serita, T., "In our own backyards: The need for a co-ordinated response to human trafficking, New York University Review of Law and Social Change, $36,2012,635-659,657$.

6 Gallagher, A., supra nt. 2, 284.

7 Carter, P. and Chandran, P., "Protecting against the Criminalisation of Victims of Trafficking: Representing the Rights of Victims of Trafficking as Defendants in the Criminal Justice System", in: Chandran, P., ed., Human Trafficking Handbook: Recognizing Trafficking and Modern-Day Slavery in the UK, LexisNexis, London, 2011, 425. 
sections set out the existing international and European regional legal frameworks and inform the fourth section, which is a critical analysis of the implementation of those frameworks in the United Kingdom. The fifth section argues that there are significant deficiencies in the existing system and that these deficiencies create a lacuna in efforts to protect the rights of trafficked persons. Further, it argues that this lacuna could be filled by the introduction of a causation-based international law model which confers a positive defence against criminalisation upon trafficked persons.

\section{The international legal framework}

An examination of the existing international legal framework reveals that the noncriminalisation principle is an accepted element of the international response to trafficking in persons. Further, it is revealed that the normative standard of protection required by international law is causation-based. Yet, despite this, there is no binding international law provision that requires states to ensure that trafficked persons are not criminalised for offences committed as a direct consequence of their status as trafficked persons. The following sub-sections set out the international legal framework in chronological order.

\section{II.1. UN Trafficking Protocol 2000}

Notwithstanding that it is the centrepiece of the international legal framework governing the response to trafficking in persons, the Trafficking Protocol does not make express provision for the non-criminalisation of trafficked persons. Kevin Fedette argues that the principle of non-criminalisation is incorporated in the Trafficking Protocol because it presents trafficked persons as 'victims'9 inferring a 'legislative link' ${ }^{10}$ between the Trafficking Protocol and the UN Declaration of Basic Principles of Justice for Victims of Crime and Abuse of Power 1985. ${ }^{11}$ Yet as Fedette himself concedes: '[G]iven the historic trend of states to criminalise victims, an express non-criminalisation clause in the Protocol would have been advisable.' ${ }^{12}$ Indeed, knowing that States Parties to the Trafficking Protocol were encouraged to include an express non-criminalisation provision and declined to do so, ${ }^{13}$ any attempt to argue that the non-criminalisation principle is incorporated into the Trafficking Protocol by inference is significantly undermined. Nevertheless, it is noteworthy that the body established to make recommendations on its effective implementation has recently affirmed that:

States parties should [c]onsider, in line with their domestic legislation, not punishing or prosecuting trafficked persons for unlawful acts committed by

8 UN Protocol to Prevent, Suppress and Punish Trafficking in Persons, Especially Women and Children, supplementing the United Nations Convention against Transnational Organized Crime ("Trafficking Protocol"), 2000, 2237 UNTS 39574.

9 The three purposes of the Trafficking Protocol are set out in Article 2. Article 2(b) provides that one of those purposes is 'to protect and assist the victims of such trafficking, with full respect for their human rights'.

10 Fedette, K., "Revisiting the UN Protocol on Human Trafficking: Striking Balances for More Effective Legislation", Cardozo Journal of International and Comparative Law, 17, 2009, 101-134, 129.

11 UN General Assembly Resolution, A/RES/40/34, 29 November 1985.

12 Fedette, K., supra nt. 9, 129.

13 Gallagher, A., supra nt. 2, 284, citing United Nations Office on Drugs and Crime, Travaux Préparatoires of the Negotiations for the Elaboration of the United Nations Convention Against Transnational Organised Crime and The Protocols Thereto, 2006, 368. 
them as a direct consequence of their situation as trafficked persons, or where they were compelled to commit such unlawful acts. ${ }^{14}$

\section{II.2. UNHCR Recommended Principles and Guidelines $2002^{15}$}

The Recommended Principles and Guidelines were designed to assist states and intergovernmental organisations in their efforts to prevent trafficking in persons and protect the rights of trafficked persons. They contain a number of express, causation-based noncriminalisation provisions. Recommended Principle 7 provides:

Trafficked persons shall not be detained, charged or prosecuted for the illegality of their entry into or residence in countries of transit and destination, or for their involvement in unlawful activities to the extent that such involvement is a direct consequence of their situation as trafficked persons. ${ }^{16}$

Further, Recommended Guideline 2 provides that states should consider, inter alia: 'Ensuring that trafficked persons are not prosecuted for violations of immigration laws or for the activities they are involved in as a direct consequence of their situation as trafficked persons',17 and, Recommended Guideline 4 provides that states should consider, inter alia: 'Ensuring that legislation prevents trafficked persons from being prosecuted, detained or punished for the illegality of their entry or residence or for the activities they are involved in as a direct consequence of their situation as trafficked person.'18

These provisions demonstrate that in 2002 there was, for the first time, recognition among states that the non-criminalisation of trafficked persons was central to efforts to ensure their protection. They have been 'extensively cited as the accepted standard' for the principle of non-criminalisation. ${ }^{19}$ Although non-binding, the Recommended Principles and Guidelines, 'form the bedrock of an understanding of the needs and rights of victims of trafficking in the particular context of their criminalisation for trafficking-dependant crimes. ${ }^{20}$

\section{II.3. Subsidiary sources of international law}

Developments since the adoption of the Trafficking Protocol demonstrate that the noncriminalisation principle, first expressed in the Recommended Principles and Guidelines, is receiving increasing support at the international level. ${ }^{21}$ The principle has been expounded in a series of UN General Assembly Resolutions, for example 63/156, which:

Urges Governments to take all appropriate measures to ensure that victims of trafficking are not penalized for being trafficked and that they do not suffer

14 United Nations Working Group on Trafficking in Persons, REPORT: Report on the meeting of the Working Group on Trafficking in Persons, 14 and 15 April 2009, [CTOC/COP/WG.4/2009/2], Vienna, para. 12.

15 UN High Commissioner for Human Rights Principles and Guidelines on Human Rights and Trafficking ("Recommended Principles and Guidelines") 2000, E/2002/68/Add.1.

16 Idem, Principle 7.

17 Idem, Guideline 2.5.

18 Idem, Guideline 4.5.

19 Gallagher, A., supra nt. 2, 286.

20 Carter, P., and Chandran, P., supra nt. 7, 406.

21 UN Office of the High Commissioner for Human Rights, REPORT: Commentary - UN High Commissioner For Human Rights Principles and Guidelines on Human Rights and Trafficking, 2010, Geneva, 131. 
from revictimization as a result of actions taken by government authorities, and encourages Governments to prevent, within their legal framework and in accordance with national policies, victims of trafficking in persons from being prosecuted for their illegal entry or residence. 22

Further, the principle has been recognised in a series of reports by the UN SecretaryGeneral, the UN Committee on the Rights of the Child and the UN Committee on the Elimination of Discrimination Against Women, major international and regional policy documents and soft-law instruments and national anti-trafficking laws. ${ }^{23}$

\section{II.4. The UNODC Model Law 2009²4}

Foremost amongst the international soft-law instruments is the Model Law, which was developed in order to encourage states to become party to the Trafficking Protocol and to provide guidance for its implementation in states' domestic legal systems. For each proposed article, the authors provide a commentary in the body of the text before the suggested provision is articulated. Article 10 is entitled 'Non-liability [non-punishment] [non-prosecution] of victims of trafficking in persons'. The commentary canvasses existing hard- and soft-law non-criminalisation provisions at regional and national levels, before suggesting the following causation-based provision:

1. A victim of trafficking in persons shall not be held criminally or administratively liable [punished] [inappropriately incarcerated, fined or otherwise penalized] for offences [unlawful acts] committed by them, to the extent that such involvement is a direct consequence of their situation as trafficked persons.

2. A victim of trafficking in persons shall not be held criminally or administratively liable for immigration offences established under national law.

3. The provisions of this article shall be without prejudice to general defences available at law to the victim.

4. The provisions of this article shall not apply where the crime is of a particularly serious nature as defined under national law. ${ }^{25}$

22 UN General Assembly Resolution 63/156, 30 January 2009, para. 12. See also UN General Assembly Resolutions: 61/144, 1 February 2007, para. 18; 59/166, 10 February 2005, paras. 8 and 18; 57/176, 30 January 2003, para. 8; 55/67, 31 January 2001, paras. 6 and 13; 52/98, 6 February 1998, para. 4; and, 51/66, 31 January 1997, para. 7.

23 UN Office of the High Commissioner for Human Rights, supra nt. 20, 132 and notes 264 to 269; Gallagher, A., supra nt. 2, 286-7 and notes 36-43.

24 UN Office on Drugs and Crime, Model Law against Trafficking in Persons ("Model Law"), 2009, Vienna.

25 Idem, Article 10. 


\section{The European legal framework}

An examination of the European legal framework reveals that in the absence of a binding international legal obligation, the principle of non-criminalisation that has developed at the regional level in Europe is, at worst, compulsion-based and, at best, ambiguous. Further, the European legal framework offers qualified protection only: Member States are required to ensure the possibility of non-criminalisation only. Trafficked persons are not endowed with a positive right to avoid prosecution for status-dependent offending behaviour; rather, they must hope that the relevant authority exercises its entitlement not to prosecute them. The following sub-sections set out the European legal framework in chronological order.

\section{III.1. Council of Europe Trafficking Convention 200526}

Article 26 of the Trafficking Convention is entitled 'Non-punishment provision' and provides for the possibility of protection from criminal sanction:

Each Party shall, in accordance with the basic principles of its legal system, provide for the possibility of not imposing penalties on victims for their involvement in unlawful activities, to the extent that they have been compelled to do so. ${ }^{27}$

Three features of this provision are problematic. First, it provides only for the nonpunishment of trafficked persons; the prosecution of such persons is not prohibited. This is significant because the process of prosecution - arrest, interview, court appearances, giving evidence and so on - is capable of re-traumatising a trafficked person as much as, if not more than, the sanction ultimately imposed, and a discretion to exempt trafficked persons does not provide an adequate remedy against such re-traumatisation. Secondly, it is qualified because it requires that states provide the possibility of non-punishment only; nonpunishment is not an imperative requirement. Thirdly, it is compulsion-based rather than causation-based (only such involvement in criminality that is 'compelled' is covered by the provision), and, as such, it offers inadequate protection against criminalisation for trafficked persons.

\section{III.2. The EU Trafficking Directive $2011^{28}$}

Article 8 of the Trafficking Directive is entitled 'Non-prosecution or non-application of penalties to the victim' and provides:

Member States shall, in accordance with the basic principles of their legal systems, take the necessary measures to ensure that competent national authorities are entitled not to prosecute or impose penalties on victims of trafficking in human beings for their involvement in criminal activities which

26 Council of Europe Convention on Action against Trafficking in Human Beings ("Trafficking Convention"), 2005, CETS 197.

27 Idem, Article 26.

28 Directive 2011/36/EU of the European Parliament and of the Council on preventing and combating trafficking in human beings and protecting its victims, and replacing Council Framework Decision 2002/629/JH ("Trafficking Directive"), 5 April 2011. 
they have been compelled to commit as a direct consequence of being subjected to any of the acts referred to in Article 2. ${ }^{29}$

The Trafficking Directive entered into force on 5 April 2011. In accordance with European Union law, Member States had two years to transpose its provisions into their domestic legal systems (by 6 April 2013). After 6 April 2013, the Trafficking Directive began to have "direct effect", which meant that those provisions which are clear, precise and unconditional must be enforced by the domestic courts of Member States.

While the Trafficking Directive extends the protection offered by the Trafficking Convention to include the non-prosecution of trafficked persons, non-prosecution and nonpunishment remain optional. The formulation whereby states must provide for 'the possibility of not' punishing trafficked persons is simply replaced by an analogous formulation whereby states must ensure that the relevant authorities 'are entitled not to' prosecute and punish trafficked persons. Both provide for the possibility of noncriminalisation, rather than making it an imperative requirement, and so the protection remains qualified.

Further, it is not clear whether the Trafficking Directive imposes a compulsion-based or a causation-based approach: the trafficked person must have been 'compelled' to commit the relevant criminal activity 'as a direct consequence' of having been trafficked. This conceptual blurring results in two possible interpretations of the provision: first, that it mandates a compulsion-based approach because some form of compulsion beyond the criminal activity being a direct consequence of the trafficking situation is required (presumably, the exertion of a high degree of pressure); or, secondly, it mandates a causation-based approach because it recognises that if the relevant criminal activity is a direct consequence of the trafficking situation then the trafficked person was compelled, in broad terms, to commit it.

Assistance in the interpretation of Article 8 of the Trafficking Directive can be found in Recital 14: 'This safeguard should not exclude prosecution or punishment for offences that a person has voluntarily committed or participated in. ${ }^{30}$ This appears to restrict the protection to circumstances in which the trafficked person was pressured to commit the criminal activity (that is, a compulsion-based approach). On the other hand, it has been argued that it is necessary to interpret Article 8 as causation-based in order to ensure that it is compliant with Member States' obligations under international law because a compulsion-based interpretation is 'too blunt a means of securing the protection required by international law. ${ }^{31}$ Certainly the formulation of Article 8 of the Trafficking Directive suggests both recognition that the protection offered by Article 26 of the Trafficking Convention was inadequate and an intention to improve that protection. ${ }^{32}$ The rationale of the regional policy makers was that:

Stakeholders have pointed out that victims of trafficking are normally detained or prosecuted or punished for minor offences which are typically connected with the victimisation process, such as violations of immigration laws, use of false documents, and prostitution, in countries where prostitution as such is criminalised. The fear of punishment and/or deportation is considered a major obstacle for victims to come forward, report the crime, and

\footnotetext{
Idem, Article 8. Article 2 defines trafficking in human beings.

Idem, Recital 14.

1 Carter, P., and Chandran, P., supra nt. 7, 406 and nt. 6.

32 Gallagher, A., supra nt. 2, 285 and supra nt. 31.
} 
act as witnesses. Therefore the clause must be considered a major element of a successful anti-trafficking legislation. A similar non-punishment clause has been included in the CoE Convention, but the formulation is not clearly binding; moreover it does not cover all victims, since it only refers to victims who have been compelled to commit a crime, while in some cases they are trafficked by means of deception and abuse, according to the legal definition of trafficking. The added value [...] would be a better and binding formulation of the clause ${ }^{.33}$

It appears, then, that the formulation of Article 8 of the Trafficking Directive was informed, at least in part, by recognition that a pure compulsion-based approach offers insufficient protection against non-criminalisation for trafficked persons. Yet the ambiguous drafting of the provision is dangerous because it allows Member States a margin to interpret the provision as purely compulsion-based.

\section{The application of the international and European legal frameworks in the domestic courts of England and Wales ${ }^{34}$}

An assessment of the existing international and European legal frameworks requires an analysis of how the provisions of those frameworks have been interpreted by and incorporated into states' domestic legal systems. I have chosen to consider the United Kingdom because it is the jurisdiction in which I practice and with which I am most familiar. The domestic interpretation of the principle of non-criminalisation can be charted through a series of four cases decided by the Criminal Division of the Court of Appeal of England and Wales between 2008 and 2013. What is revealed is an interpretation that is both compulsion-based and qualified. The following sub-sections consider the four cases in chronological order.

\section{IV.1.Regina $v O^{35}$}

In $O$ the Court considered the appeal against conviction of a female Nigerian national who had been trafficked into the United Kingdom for the purposes of sexual exploitation and was arrested trying to leave the jurisdiction using a false identity card. She had told her legal representatives that she was seventeen years old, and a social worker had assessed her to be credible. Having advised her to plead guilty to the offence (which she did), O's lawyer at first-instance had informed the first-instance court that she was aged seventeen but failed to raise the issue of trafficking (despite a letter from the social worker being among his papers). Indeed, neither O's lawyer nor the prosecutor had considered either of two protocols ${ }^{36}$

33 Commission of the European Communities, REPORT: Accompanying Document to the proposal for a Council Framework Decision in preventing and combating trafficking in human beings, and protecting victims, repealing Framework Decision 2002/629/HJA, Impact Assessment, 25 March 2009, COM (2009) 135, SEC (2009) 356, Brussels, 30. The relevant provision of the Framework Decision 2009 Proposal was essentially identical to Article 8 of the Trafficking Directive, see Gallagher, A., supra nt. 2, 285 and 31.

34 Scotland and Northern Ireland are distinct legal jurisdictions.

35 Regina v $O$ [2008] EWCA Crim 2835 (“O”).

36 Entitled: 'Protocol on prosecution of defendants charged with immigration offences who might be trafficked to victims'; and, 'Protocol on prosecution of young offenders charged with offences who might be trafficked victims'. They have since been replaced by Crown Prosecution Service guidance on the prosecution of trafficked persons. 
which had been incorporated into the Code for Crown Prosecutors in order to give effect to the Trafficking Convention (which the United Kingdom had not yet ratified). The court made no enquiries about O's age and treated her as an adult in sentencing her to eight months' imprisonment.

In allowing O's appeal and quashing her conviction the court was excoriating in its criticism of the defence lawyer, the prosecution lawyer and the sentencing judge:

This appeal against conviction must obviously be allowed. We would put it most simply on the footing that the common law and Article 6 of the European Convention on Human Rights alike require far higher standards of procedural protection than were given here. There was no fair trial. We hope that such a shameful set of circumstances never occurs again. Prosecutors must be aware of the protocols which, although not in the text books are enshrined in their Code. Defence lawyers must respond by making enquiries, if there is before them credible material showing that they have a client who might have been the victim of trafficking, especially a young client. Where there is doubt about the age of a defendant who is a possible victim of trafficking, proper inquiries must be made, indeed statute so required. All this is obvious. ${ }^{37}$

O's appellate lawyers had argued that, despite not yet being in force, Article 26 of the Trafficking Convention applied, because as a signatory to it, the United Kingdom was obliged to refrain from acts which would defeat its object and purpose under Article 18 of the Vienna Convention on the Law of Treaties 1969. By framing its decision in terms of O's right to a fair trial (under the English common law and Article 6 of the European Convention on Human Rights), the Court avoided determining the issue of the applicability of Article 26 of the Trafficking Convention.

\section{IV.2.Regina v LM; YT;BT; DG; MB ${ }^{38}$}

$L M$ was decided after the ratification of the Trafficking Convention so the argument centred on whether the United Kingdom was compliant with the obligations imposed. The Court offered the following analysis of the scope of Article 26:

It is necessary to focus upon what Article 26 does and does not say. It does not say that no trafficked victim should be prosecuted, whatever offence has been committed. It does not say that no trafficked victim should be prosecuted when the offence is in some way connected with or arises out of trafficking. It does not provide a defence which may be advanced before a jury. What it says is no more, but no less, than that careful consideration must be given to whether public policy calls for a prosecution and punishment when the defendant is a trafficked victim and the crime has been committed when he or she was in some manner compelled (in the broad sense) to commit it. Article

Supra nt.35, para. 26.

38 Regina v LM; YT; BT; DG; MB [2010] EWCA Crim 2327 (“LM”). 
26 does not require a blanket immunity from prosecution for trafficked victims. ${ }^{39}$

The Court found that three domestic mechanisms, taken cumulatively, ensured compliance with the non-punishment provision of the Trafficking Convention: first, the defence of duress; secondly, the exercise of the prosecutorial discretion not to prosecute; and, thirdly, the power of the court to stay the prosecution as an abuse of process. ${ }^{40}$ Considering the defence of duress, the Court considered that no special modification was required and that the defence would arise in relation to trafficked persons when they had been coerced into committing the offence in question. The obvious deficiency with the defence of duress is that it requires a threat of death or serious injury to the trafficked person or someone sufficiently close to them. Further, it is defeated if evasive action that is reasonably available is not taken (the Court gave the examples of failing to notify the authorities and voluntarily associating with the trafficker were given). ${ }^{41}$

Considering the exercise of the prosecutorial discretion not to prosecute, the Court examined the Crown Prosecution Service's guidance on the prosecution of trafficked persons ${ }^{42}$ and found that it imposed a 'three-stage exercise of judgment': ${ }^{43}$

The first is: (1) is there a reason to believe that the person has been trafficked? If so, then (2) if there is clear evidence of a credible common law defence the case will be discontinued in the ordinary way on evidential grounds, but, importantly, (3) even where there is not, but the offence may have been committed as a result of compulsion arising from the trafficking, prosecutors should consider whether the public interest lies in proceeding to prosecute or not. $^{44}$

Considering the availability of an application-to-stay proceedings as an abuse of process, the Court found that the jurisdiction could be used to ensure that a 'legal process to which a person is entitled, or to which he has a legitimate expectation, has [not] been neglected to his disadvantage ${ }^{45}$. So while an application for a stay might succeed if it could be demonstrated that the prosecutor had failed to consider the Crown Prosecution Service guidance, the application would fail if the prosecutor had considered the guidance before going on to make a decision to prosecute. In such circumstances, courts would only have

39 Supra nt. 35, para. 13. Thus, the Court considered that Article 26 of the Trafficking Convention called for consideration of whether public policy necessitates the prosecution and punishment of the trafficked person. This is a commendably broad interpretation of Article 26: on a narrower interpretation, all that is required is that upon prosecution and conviction consideration is given to whether the public policy necessitates punishment (because Article 26 is a non-punishment, rather than non-prosecution, provision).

Idem, para. 7.

41 Idem, para. 8.

42 The Court cited the following excerpt at para. 9: 'Victims of human trafficking may commit offences whilst they are being coerced by another. When reviewing such a case it may come to the notice of the prosecutor that the suspect is a "credible" trafficked victim. For these purposes "credible" means that the investigating officers have reason to believe that the person has been trafficked. In these circumstances prosecutors must consider whether the public interest is best served in continuing the prosecution in respect of the offence. Where there is evidence that a suspect is a credible trafficked victim, prosecutors should consider the public interest in proceeding. Where there is clear evidence that the defendant has a credible defence of duress, the case should be discontinued on evidential grounds'.

43 Supra, nt. 35, para. 10.

44 Ibid.

45 Idem, para. 15. 
the power to review the exercise of the prosecutorial discretion if the decision to prosecute was unreasonable. ${ }^{46}$

Having established these essential principles, the court went on to consider the particular facts of the five appellants' appeals, four of which are relevant for the purposes of this article. LM, DG and MB were three women jointly convicted of offences of controlling prostitution. ${ }^{47}$ From the outset, the case against these women was that although they had originally been trafficked persons, they had subsequently assumed the role of controllers of prostitution, and had used threats, violence and sexual abuse in so doing. Shortly before trial, the prosecution accepted guilty pleas from the three women on the agreed basis that: (1) they had not perpetrated violence, threats or sexual abuse; (2) they had been trafficked, beaten and coerced into prostitution themselves; and, (3) anything which had amounted to controlling prostitution had been done under pressure, albeit pressure falling short of the defence of duress. ${ }^{48}$

The Court allowed their appeal and quashed their convictions. The prosecutor had considered the Crown Prosecution Service guidance and come to a reasonable decision to prosecute (because force and threats had moved them from being victims only to being exploiters of others). However, there had been a fundamental change in the situation once their bases of plea were accepted, and the question of whether it was in the public interest to prosecute was not revisited. Had this been done, Further, had the question been revisited, no reasonable prosecutor would have continued the prosecution. Thus, the convictions were quashed under the abuse of process jurisdiction. ${ }^{49}$

YT was a Nigerian national convicted of using a false identity document and fraud by producing a false national insurance card. ${ }^{50}$ She claimed that she had been trafficked to the United Kingdom, for the purposes of sexual exploitation. After two years YT had been abandoned by her trafficker and, three to four months later she found part-time employment at a care home. She had produced the false documents when subsequently applying for a full-time position. ${ }^{51}$ She had been assessed as credible by a social worker, yet the Court dismissed her appeal and upheld her conviction:

What however is clearly fatal to any reliance upon the convention is the fact that for some months before the offences were committed the defendant had been entirely free of any exploitation, which she may have suffered, and had been living a wholly independent life. Certainly she was living as an illegal immigrant, but that is quite different from remaining a trafficked victim, or being in the course of flight from such a position. It cannot be said that she committed the offences in an effort to escape her trafficked exploitation,

46 Idem, para. 19.

47 BT had been convicted following a guilty plea to an offence of possessing a false identity document. She had been arrested en route to France. She had been convicted despite her claim that she was a trafficked person and had been attempting to escape her traffickers. The Court found that were her claim true, Article 26 would apply, and the failure to consider whether or not the public interest lay in her being prosecuted would have been a clear breach. However, the Court found her claim not to be credible and dismissed her appeal. Plainly, if a person cannot demonstrate that they are a trafficked person, they will not be entitled to benefit from the principle of non-criminalisation. Yet BT was found to be incredible notwithstanding that she had been assessed to be credible by a social worker and an immigration court. This is demonstrative of the entrenched culture of incredulity facing trafficked persons when attempting to establish their traffickedstatus. While this is, of course, a serious problem, it is beyond the scope of this article.

48 Supra, nt. 35, paras. 24-34.

49 Idem, paras. 24-34.

50 A national insurance number is a pre-requisite for working lawfully in the United Kingdom.

51 Supra, nt. 35, paras. $41-47$. 
because she had long been free of it. The reality is that she committed the offences because she wished to continue to live, unlawfully, in this country, and to work here when she was not entitled to do so. It may be understandable that she should do this, but so it is for many illegal immigrants. The offences were not committed under the necessary nexus of compulsion (in the broad sense) with her trafficking. ${ }^{52}$

The word 'compelled' in Article 26 of the Trafficking Convention renders it unequivocally compulsion-based and, accordingly, it was so interpreted by the Court in $L M$. While the Court recognised that Article 26 went further than the defence of duress, it found that a degree of compulsion (in a broader, undefined sense) was still required for Article 26 to apply.

YT's case starkly demonstrates a flaw in the compulsion-based approach: YT had been trafficked from Nigeria for the purpose of sexual exploitation and had been subjected to horrifying sexual abuse, daily for two years. There can be no doubt that she was deeply traumatised by her experiences. As an illegal migrant, it is highly probable that she was too fearful of the authorities to seek their help. Further, as a trafficked person, it is quite possible that she would feel too ashamed to seek help from her family or a non-governmental organisation (even if she had been aware of the availability of the latter). In order to avoid becoming destitute, she used false documents to obtain employment (it is noteworthy that she was working in the public sector and was no doubt paying income tax and national insurance) and yet she was subjected to the re-traumatising experience of being arrested, interviewed, prosecuted, convicted and imprisoned. ${ }^{53}$ Her conviction (and thus the validity of this experience) was upheld by the Court of Appeal because she had not demonstrated a sufficient degree of compulsion. Conversely, had a causation-based approach been applied, YT could have argued that her criminality was caused by the trafficking situation: but for the trafficking situation she would not have been a destitute, traumatised and lone illegal migrant in a foreign country, forced into criminality in order to survive.

A further fundamental flaw in the language of Article 26 of the Convention is exposed in $L M$. Article 26 requires the provision of the 'possibility' of non-punishment, which the Court found to be satisfied by the exercise of the prosecutorial discretion. As long as a prosecutor were to give due consideration to the Crown Prosecution Service guidance and whether or not it was in the public interest to prosecute the trafficked person, the requirements of the Trafficking Convention would be fulfilled. In such circumstances, the only basis on which a court could intervene would be if the decision was unreasonable. This would require the trafficked person to demonstrate that the decision to prosecute was so unreasonable that no reasonable prosecutor acting reasonably could have come to it; this is an exceptionally high threshold. ${ }^{54}$ The necessity to rely on the sensible and compassionate exercise of the prosecutorial discretion inadequately protects trafficked persons and (once again) disempowers them. What is required is a substantive weapon that is a part of their arsenal rather than a discretionary mercy which might or might not benevolently be bestowed upon them.

52 Idem, para. 45.

53 It is noteworthy that the Court reduced YT's sentence from 9 months' imprisonment to 4 months' imprisonment because her status as a (former) trafficked person was a relevant mitigating factor. Supra, nt. 35, para. 47.

54 UK Court of Appeal, Associated Provincial Picture Houses Ltd. v Wednesbury Corporation, [1948] 1 KB 223. A full discussion of public law reasonableness is beyond the scope of this paper. 


\section{IV.3.Regina $v N ; L e^{55}$}

The issue in the appeals of $\mathrm{N}$ and LE was whether the decisions to prosecute them were an abuse of process. The appellants were Vietnamese nationals, assessed as being aged 17 and 18 , respectively, at the dates of their convictions, who had worked as gardeners in cannabis factories and were convicted of producing a controlled drug. They received sentences of 18 months' and 20 months' detention.

$N$ demonstrates the flaw in relying on the reasonable exercise of prosecutorial discretion to ensure the non-criminalisation of trafficked persons. Both $\mathrm{N}$ and Le had been assessed as credible by social workers and the United Kingdom Borders Agency. In N's case, there was evidence that he was locked in the factory and not allowed to leave, that he was unpaid, that he was unaware that the plants were illegal and that he was told that he would be killed if he tried to escape. Similarly, in Le's case, there was evidence that he was unpaid and coerced into working in the factory under threats of violence. Yet despite this evidence, in exercising its power of review, the Court found that in each case the prosecution had followed the relevant guidance and had come to a reasonable decision that it was in the public interest to prosecute.

In N's case, the Court found that the prosecutor's decision to prosecute was justified because there was evidence that $\mathrm{N}$ was a volunteer who had been smuggled into the country to make a better life for himself and that he had a family member in the United Kingdom, to whom he could have turned. In Le's case, there was evidence that on arrest he had been found with cash and a mobile telephone and that he had been provided with food at weekly intervals. In short, the Court found there was sufficient evidence for a prosecutor reasonably to consider that $\mathrm{N}$ and Le had not been compelled within the meaning of Article 26. While the exercise of the prosecutorial discretion in these cases might have been reasonable in the public law sense, it was anathematic to the fundamental purpose of the non-criminalisation principle: ensuring that trafficked persons are not re-traumatised by being prosecuted for offences which are caused by the trafficking situation.

\section{IV.4.Regina $v$ L, HVN, THN, T}

$L$ was the first case to be decided after the Trafficking Directive became directly effective. The Court did not provide any analysis of how the requirements of Article 8 of the Trafficking Directive differed from those of Article 26 of the Trafficking Convention; rather, the Court found that Article 8 'echoe[d]' ${ }^{57}$ Article 26 and that the tripartite procedure set out in $L M$, and endorsed in $N$, provided 'sufficient vindication for the rights enshrined in the EU Directive as well as the Anti-Trafficking Convention' ${ }^{58}$

The Court went on to consider the four appellants' appeals. The cases of HVN, THN and $\mathrm{T}$ were factually similar: all three were Vietnamese nationals who had worked as gardeners in cannabis factories and were convicted of offences relating to the production of a controlled drug. All three appeals were allowed, and the appellants' convictions quashed, on the basis of strong evidence that they were trafficked children, who had been compelled to commit the criminal activities of which they had been convicted. On the basis of the evidence available at appeal, the Court found that if each appellant had been prosecuted

\footnotetext{
55 Regina v N; Le [2012] EWCA Crim 189 ("N").

56 Regina v L, HVN, THN, T, [2013] EWCA Crim 991 ("L").

57 Supra nt. 55, para. 8.

58 Idem, para. 18.
} 
then, an abuse of process argument would have been likely to succeed. ${ }^{59}$ The facts of HVN, THN and T's cases did not differ greatly from those of $\mathrm{N}$ and Le in $N$, but in $L$ the Court based its decision on the evidence available at the date of the appeal, rather than the evidence available at the time that the decision to prosecute was made. In so doing, the Court took a progressive, proactive approach to its power of review.

$\mathrm{L}$ was a female national of Uganda in her mid-thirties, who had been convicted of possessing a false identity document. She had been arrested after producing a false passport in support of an application for a national insurance card. She had been trafficked for the purposes of sexual exploitation from Uganda. After several years of enforced prostitution she had been released by her trafficker who gave her a passport that she believed was genuine and she was entitled to. She had been released several months before her arrest. ${ }^{60}$ In allowing her appeal and quashing her conviction the Court held:

Given the appellant's prolonged exposure to involuntary prostitution and enforced control, the offence she actually committed appears to us to have arisen as a result of her being a victim of trafficking who was provided with a forged passport for her to use as if it were genuine, and the use of it represented a step in a process by which she would escape. On the basis of the facts which are now known, if this appellant had been prosecuted, an abuse of process argument would have been advanced with a realistic prospect of success. ${ }^{61}$

The facts of L's case were almost identical to those of YT's in LM. In YT's case the Court found that there was an insufficient connection between the trafficking situation and the offending behaviour such that it had not been compelled within the meaning of Article 26 of the Trafficking Convention. In L's case the Court found that her use of the false passport was a step in the escape process. Once again, the Court took a progressive, proactive approach to its power of review. Indeed, the decision in L's case was even more progressive than those in the cases of HVN, THN and T because L had already escaped her trafficker precisely as YT had done. In effect, by finding that L's offence arose 'as a result' of the trafficking situation, the Court employed a causation-based approach.

Nevertheless, despite a bold application of the law to the particular facts of the appellants' cases, the Court in $L$ did nothing to change the de jure position in the United Kingdom, namely that the compulsion-based requirements of the Trafficking Convention and the Trafficking Directive are met by three mechanisms: the defence of duress, the exercise of the prosecutorial discretion and the availability of a stay of proceedings as an abuse of process. As demonstrated by the cases of YT in $L M$ and $\mathrm{N}$ and Le in $N$, this approach does not offer trafficked persons sufficient protection against non-criminalisation.

Idem, paras. 35-67.

60 Idem, paras. 68-74.

61 Idem, para. 74. 


\section{A proposed model for the non-criminalisation of trafficked persons in international law}

\section{V.1. Deficiencies in the existing system}

The analysis of the operation of the international and European legal frameworks governing the non-criminalisation of trafficked persons in the domestic law of the United Kingdom demonstrates that the existing system has a number of significant deficiencies that result in a lacuna in efforts to protect the rights of trafficked persons.

Most significantly, there is no binding international law obligation to refrain from criminalising trafficked persons. In many ways, the Trafficking Protocol has been a great success. It has provided an authoritative definition of trafficking in persons. It tackles critical practicalities such as criminal jurisdiction, mutual legal assistance and extradition. It is linked to a parent instrument which combats corruption, provides for the exchange of evidence between states and establishes a mechanism by which the assets of offenders may be confiscated. It has provoked a swathe of legal and policy reforms at both regional and national levels which have had a profound (and predominantly positive) impact on the way in which trafficking in persons, and trafficked persons themselves, are dealt with at ground level. Perhaps most significantly, the adoption of the Trafficking Protocol has focused 'global attention and resources on debt bondage, forced labour, sexual servitude, forced marriage and other exploitative practices that continue to plague all regions and most countries of the world. ${ }^{\prime 62}$

However, for all its successes, the Trafficking Protocol fails properly to protect trafficked persons from criminalisation for offences committed as a consequence of the trafficking situation. While developments since the adoption of the Trafficking Protocol demonstrate that there is broad consensus at the international level that the principle of noncriminalisation is an essential element of the framework for protecting trafficked persons, there exists no international legal provision capable of binding national courts. This is amply demonstrated by the conspicuous absence of any discussion of public international law in the judgments of the Court of Appeal in $O, L M, N$ and $L$.

The absence of a binding non-criminalisation provision in international law is significant because it means that there is no unified vision to which regional and national legislators may (or must) adhere. This contributes to (and exacerbates) the remaining significant deficiencies in the existing system. While the international soft-law provisions are wholly causation-based (the Recommended Principles and Guidelines and the Model Law are both entirely devoid of the language of compulsion), in the absence of a binding international law provision, the European regional system has adopted a compulsion-based approach in giving effect to the non-criminalisation principle. The compulsion-based approach fails to recognise that even in the absence of any threat or use of force, or direct pressure or coercion, a trafficked person might be left with no realistic alternative but to commit a criminal offence (even after the trafficking situation has ended).

In the United Kingdom, the significance of the regional system cannot be overstated because no non-criminalisation provision has been transposed into domestic law. Further, the interpretation of Article 8 of the Trafficking Directive in $L$ (notwithstanding the generous judgments on the particular facts of the appellants' cases) means that the apparent attempt to move towards a causation-based approach at the regional level has not filtered

62 Gallagher, A.T., "Human Rights and Human Trafficking: Quagmire or Firm Ground? A Response to James Hathaway", Virginia Journal of International Law, vol. 49, ed. 4, 2009, 789—848, 793. 
down to the domestic level. ${ }^{63}$ The Court found that there was no difference between Article 8 of the Trafficking Directive and Article 26 of the Trafficking Convention: both were purely compulsion-based, requiring something more than the offence being committed as a direct consequence of the trafficking situation.

Similarly, in the absence of a binding international provision to the contrary, the regional system in Europe has developed in such a way that the requirements of the noncriminalisation provision are qualified: they are satisfied by the provision of the possibility of non-punishment and non-prosecution. In the United Kingdom, the Court of Appeal has found that this requirement is fulfilled by the defence of duress, the exercise of the prosecutorial discretion and the court's limited power of review through the abuse of process jurisdiction. ${ }^{64}$ In situations where duress is not available (that is, the vast majority of situations) the trafficked person is thus left to rely on a prosecutor deciding that it is not in the public interest to prosecute them. A court is only able to intervene if the prosecutor fails to consider the Crown Prosecution Service guidance or acts unreasonably.

This does not provide adequate protection because the power is placed entirely in the hands of the prosecutor. Trafficked parties do not have the right to defend themselves by asserting that the offence was committed as a result of the trafficking situation; rather, they must ask the prosecutor (who, it must be remembered, represents the opposing party in the litigation and, thus, has interests and motivations that diverge manifestly from those of the trafficked person) for mercy. If the prosecutor refuses, as long as the decision to continue with the prosecution is not so unreasonable that no reasonable prosecutor acting reasonably could have come to it, a court has no power to intervene. Perhaps unsurprisingly, the exigencies of security (specifically, the "prevention" of crime and effective immigration control) are thus reified at the expense of the rights of trafficked persons.

The absence of a binding international law provision has allowed regional and national systems in Europe to develop mechanisms to give effect to the non-criminalisation principle which are deficient in two significant respects: first, they are compulsion-based; and, secondly, they are qualified. The deficiencies produce a lacuna in the system of protections for trafficked persons. If they cannot demonstrate that they were compelled to commit the offence, or if a prosecutor decides that it is in the public interest to prosecute, they are not protected against criminalisation and the re-traumatisation that criminalisation entails. The absence of a binding international law provision has allowed these deficiencies to emerge and flourish. Consequently, the proposed model seeks to uproot and overcome these deficiencies through the introduction of such a binding provision.

63 See L, supra nt. 5, 52 .

64 See L, supra nt. 52. 


\section{V.2. The proposed model}

Of course, following the Recommended Principles and Guidelines and the Model Law, the proposed model is causation-based. Such an approach is mandated by the obligation to protect and assist trafficked persons with full respect for their human rights. Trafficked persons often commit offences in the absence of a high degree of pressure, and yet the offending behaviour remains a direct consequence of the trafficking situation. The compulsion-based approach is incapable of dealing with the subtle realities of trafficking in persons. However, the proposed model goes further than the settled, causation-based model that is established in international soft-law. What is proposed is a positive defence against criminalisation: the trafficking defence. ${ }^{65}$

Similarly to the defences of self-defence or duress, the trafficking defence would apply even when all the requisite elements of an offence are present, which means that 'the accused admits that he has voluntarily committed what is prima facie a crime with the state of mind normally sufficient for that offence, but at the same time asserts some special circumstances which he claims excuse or justify his actions. ${ }^{\prime 66}$ For example, the defence of self-defence applies when the accused admits the deliberate application of force to another, but simultaneously asserts that she or he used only such force as was reasonable in the circumstances to protect against the infliction of unlawful physical harm by that other person. If successfully established, ${ }^{67}$ self-defence is a complete defence against criminal liability.

The trafficking defence would operate in a similar manner. The trafficked person would not challenge committing the crime or its constituent elements. Rather, she or he would seek to rely upon the trafficking defence as a complete defence against criminal liability. In order to establish the defence, it is proposed that the trafficked person would need to establish: first, that they are (or were) a trafficked person; and, secondly, that the offence was committed as a direct consequence of the trafficking situation. If both elements were established, then the trafficked person would have a complete defence.

Of course, the trafficking defence could be invoked only upon the commencement of a criminal prosecution. Therefore, it is proposed that that the trafficking defence would work in tandem with an ordinary causation-based non-criminalisation provision allowing discretionary non-prosecution and non-punishment to continue. However, if a trafficked person is faced with a prosecutor who is determined that the public interest lies with prosecution, then the trafficking defence would empower them to protect themselves against criminalisation (if not arrest, interview and prosecution). Importantly, the primary role in assessing the credibility of the trafficked person would be removed from the prosecutor and vested in the court.

It is important to recognise that the trafficking defence does not protect trafficked persons from the re-traumatising experience of being prosecuted:

65 See generally Cross, L., supra nt. 4. Cross notes that eight States of the United States of America already provide trafficked persons with an affirmative defence in certain circumstances.

66 Hooper, A and Ormerod, D., Blackstone's Criminal Practice, 22 ${ }^{\text {nd }}$ ed., Oxford University Press, Oxford, 2011, 48.

67 In the United Kingdom, once self-defence is raised by the defendant, the prosecutor must demonstrate on the balance of probabilities that the defendant was not acting in self-defence. However, the proposed model does not seek to dictate the operation of the standard and burden of proof when the trafficking defence is raised. Such matters would be governed by the basic principles of states' domestic legal systems. 
'Rather, by the time this relief is available to a trafficking victim, the criminal justice system already arrested, charged, and prosecuted the defendant as a criminal rather than recognizing him or her as a victim of crime. Therefore, while providing an affirmative defense for crimes committed while the defendant was a trafficking victim is an important form of relief for when trafficking victims slip through the cracks, it does not combat dual victimization. ${ }^{68}$

Nevertheless, while it is important to recognise this fundamental shortcoming of the proposed model, the trafficking defence would provide a substantive mechanism by which trafficked persons would be empowered to protect themselves against criminalisation.

The model would be incorporated into the international legal framework by way of an amendment to the Trafficking Protocol in the form of an additional clause. While international treaties are ordinarily drafted to be unlimited in duration and are thus characterised by their stability, there are nevertheless times when their provisions must be amended. The standard process by which international treaties may be amended is set out in Article 40 of the Vienna Convention on the Law of Treaties but applies only when the treaty in question does not have an amendment clause. The Trafficking Protocol has such a clause: Article 18, entitled 'Amendment'. It provides that after the expiry of five years from the entry into force of the Protocol, a State Party may propose an amendment by filing it with the UN Secretary-General. The amendment is then communicated to the other States Parties and the Conference of the Parties to the Convention who must consider and decide upon the proposal. In the absence of consensus, a two-thirds majority vote of States Parties is required for an amendment to be adopted. The amendment would then be subject to the ordinary process of ratification, acceptance or approval.

In all likelihood the process of agreeing on an amendment and bringing it into force would be fraught with technical and political difficulties: 'the process [...] can be as difficult as negotiating and bringing into force the original treaty, and sometimes even more troublesome. ${ }^{69}$ The process is difficult because, like any progressive public international law development, it requires consensus between a multiplicity of states, each with a distinct political, legal and moral culture. While there would, of course, be a myriad of political and technical practicalities involved in the amendment of the Trafficking Protocol, these practicalities should not deter progressive developments; rather, they must be engaged and overcome. It is posited that an additional clause in the following terms would constitute a progressive development:

Non-criminalisation

1. Trafficked persons shall not be criminalised (including by being arrested, detained, interviewed, charged, prosecuted or punished) for their involvement in unlawful activities to the extent that such involvement is a direct consequence of their status as trafficked persons.

2. Trafficked persons shall have a complete defence against liability for their involvement in unlawful activities to the extent to which such involvement is a direct consequence of their status as trafficked persons.

68 Cross, L., supra nt. 4, 409.

69 Aust, A., Modern Treaty Law and Practice, $2^{\text {nd }}$ ed., Cambridge University Press, Cambridge, $2007,262$. 


\section{Conclusion}

What has been proposed is an amendment to the Trafficking Protocol to add a causationbased non-criminalisation clause which would include a positive defence against criminalisation for trafficked persons. While there can be no doubt that such a proposal would face staunch criticism among those who value security above all, reform is imperative to alleviate the on-going criminalisation, and consequent re-traumatisation, of trafficked persons. Despite being an accepted normative standard at the international, regional and national levels, the principle of non-criminalisation (in its present manifestation) fails in its eponymous aim; the truth at ground level is that instances of trafficked persons being criminalised for offences committed as a direct consequence of the trafficking situation remain common.

If adopted, it is hoped that the proposed international law model would provide an overarching vision which would lead to consequential amendments at regional and national levels and, ultimately, to the implementation of a more substantive realisation of the principle of non-criminalisation for trafficked persons at ground level.

www.grojil.org 